\title{
Gifted Education and Talent Support in Germany ${ }^{1}$
}

\author{
Christian Fischer $^{\star 2}$ And Kerstin MÜller ${ }^{3}$
}

$\approx \quad$ While the focus in Germany was initially on disabled children only, the promotion of gifted and talented children has become increasingly important. Different organisations and institutions, ranging from parents' associations to foundations, offer a large variety of measures catering for the special demands of gifted and talented children, enabling the exchange of information on giftedness and the cooperation of different institutions. Talented children are also provided with access to scholarships as well as to special academies and competitions on different topics. Furthermore, educators and researches involved in the promotion of giftedness can attend conferences as well as gaining qualifications as specialists in gifted education and talent support. In addition to these nationwide, extracurricular measures, the individual federal states offer various acceleration and enrichment activities for children with high abilities at school. Overall, this leads to a diverse system of gifted education and talent support in Germany. It does, however, mean that Germany lacks a common national strategy of gifted education and talent support due to the lack of networking of the individual federal states. By exchanging ideas and information on their applied concepts of ability promotion, the federal states could benefit from each other's expertise and experiences. Further improvement could be achieved if concepts of gifted education and talent support were to become an integral part of various discussions, such as those on inclusive education or on the results of international comparative studies (e.g., PISA, PIRLS or TIMSS).

Keywords: gifted education, talent support, Germany, federal states, foundations, associations, enrichment, acceleration

1 The article contains translations of German terms, which were translated into English by the authors of this article.

2 *Corresponding Author. International Centre for the Study of Giftedness, Universität Münster, Germany; ch.fischer@uni-muenster.de

3 International Centre for the Study of Giftedness, Universität Münster, Germany 


\section{Izobraževanje nadarjenih in spodbujanje talentiranih $\mathrm{v}$ Nemčiji}

Christian Fischer ${ }^{*}$ IN Kerstin Müller

$\approx$ V Nemčiji so bili v začetku osredinjeni predvsem na otroke s posebnimi potrebami, zdaj pa je vedno pomembnejše tudi področje spodbujanja nadarjenih in talentiranih otrok. Različne organizacije in ustanove - od združenj staršev do različnih fundacij - ponujajo različne dejavnosti za posebne zahteve nadarjenih in talentiranih otrok. Poleg tega med njimi potekajo izmenjava informacij o nadarjenosti in različne vrste sodelovanj. Talentirani otroci imajo tudi možnost pridobiti različne štipendije, imajo dostop do posebnih akademij, zanje so organizirana tekmovanja na različnih področjih. Poleg tega se učitelji in raziskovalci, povezani s promoviranjem nadarjenosti, lahko udeležujejo konferenc ter pridobijo specializacijo na področju izobraževanja nadarjenih in podpore talentiranim. Poleg teh nacionalnih zunajkurikularnih ukrepov posamezne zvezne države ponujajo veliko obogatitvenih dejavnosti za sposobnejše otroke tudi v šoli. To vodi v raznolikost sistema izobraževanja nadarjenih in spodbujanja talentov v Nemčiji. V Nemčiji tako manjka skupna nacionalna strategija izobraževanja nadarjenih in spodbujanja talentov, tudi zaradi pomanjkanja mreženja med posameznimi zveznimi državami. Z izmenjavo informacij o implementiranih konceptih promoviranja nadarjenih bi zvezne države lahko pridobile ustrezne izkušnje in strokovna znanja. Izboljšanje bi lahko dosegli tudi s tem, da bi se o tematiki razpravljalo na različnih strokovnih področjih, kot na primer inkluzivno izobraževanje ali rezultati mednarodnih primerjalnih študij (npr. PISA, PIRLS, TIMSS).

Ključne besede: izobraževanje nadarjenih, podpora talentom, Nemčija, zvezne države, fundacije, združenja, obogatitvene dejavnosti, hitrejše napredovanje 


\section{Introduction}

The promotion of gifted and talented children is becoming increasingly important in Germany. Originally, the focus was on disabled children, as it was assumed that talented children can easily deal with their learning process and thus would not need extra support. Following the principle of equal opportunities, the school system therefore catered for disabled children. In some cases, this issue can still be found in the current debate on inclusion. While the idea of inclusion as stated in the Salamanca Statement and Framework for Action on Special Needs Education (1994) covers all children regardless of their abilities, some concepts of inclusion use a narrow understanding of inclusion, such as Klemm's study "Inklusion in Deutschland" (2013), which was published by the Bertelsmann Foundation. In these cases, the main focus is on children with special educational needs. With regard to the promotion and support of talented children, organisations and institutions outside the school context were the first to cater for the specific demands of highly able children. The reason why non-state institutions, such as parents' associations, deal with the promotion of giftedness is that, on the individual level, it is parents who, being in close contact with their children, were the first to notice their special needs for additional challenges. On the societal level, foundations (usually associated with industrial companies) discovered the advantages of gifted children for Germany's economic development. In recent years, however, the identification and promotion of special abilities have been given greater attention by schools and preschools. This development of increased engagement - especially of primary schools, but also of secondary schools in German-speaking countries - was mainly evidenced by the inventory on "Gifted Education in 21 European Countries" by Mönks and Pflüger (2005), which noted a growing number of schools in which adequate first steps were taken to identify talents and to provide appropriate talent support facilities, often in "regular” classes. Still, Germany's results in international comparative studies on education, such as PISA (e.g., Prenzel et al., 2014; Klieme et al., 2010) or PIRLS and TIMSS (e.g., Bos et al., 2012), reveal a noticeable backlog demand for the identification and individual promotion of high abilities and learning competences, particularly with regard to adequate classroom-related promotion offers, which are especially required in secondary schools. This issue is closely related to the need to distinguish between performance and potential, and it intensifies the discussion on talent support and the promotion of gifted children, as it shows that there is a need to support higher achieving students. 
In order to comprehend the situation of gifted education and talent support in Germany, a general understanding of the complexity of Germany's school system, and of the relationship between the federal states and the Federal Government, is necessary. A short overview of the main aspects of the education and legislative system will therefore be provided first. In Germany, the principle of federalism forms an important constituent for education legislation, as the individual federal states dispose of "cultural sovereignty", meaning that each federal state is responsible for its own education and cultural policy. Therefore, the federal states can individually decide on educational issues, as long as their decisions are in accordance with the Federal Government. This leads to diverse measures with regard to the education and school system. However, the institution of the "Conference of the Ministers of Education and Cultural Affairs" enables federal states to cooperate with each other (KMK, 2013). While there are derivations in some federal states, the following diagram provides an overview of the German education system:

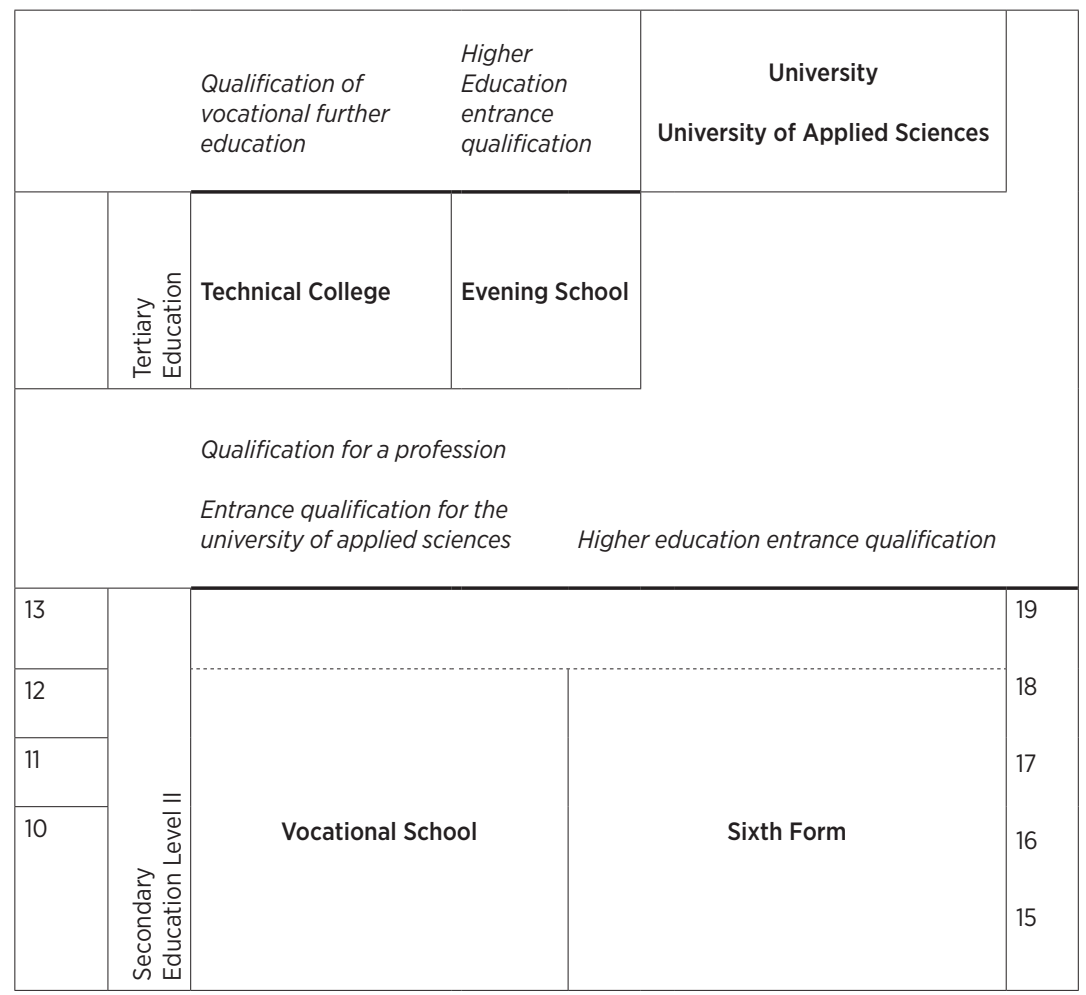




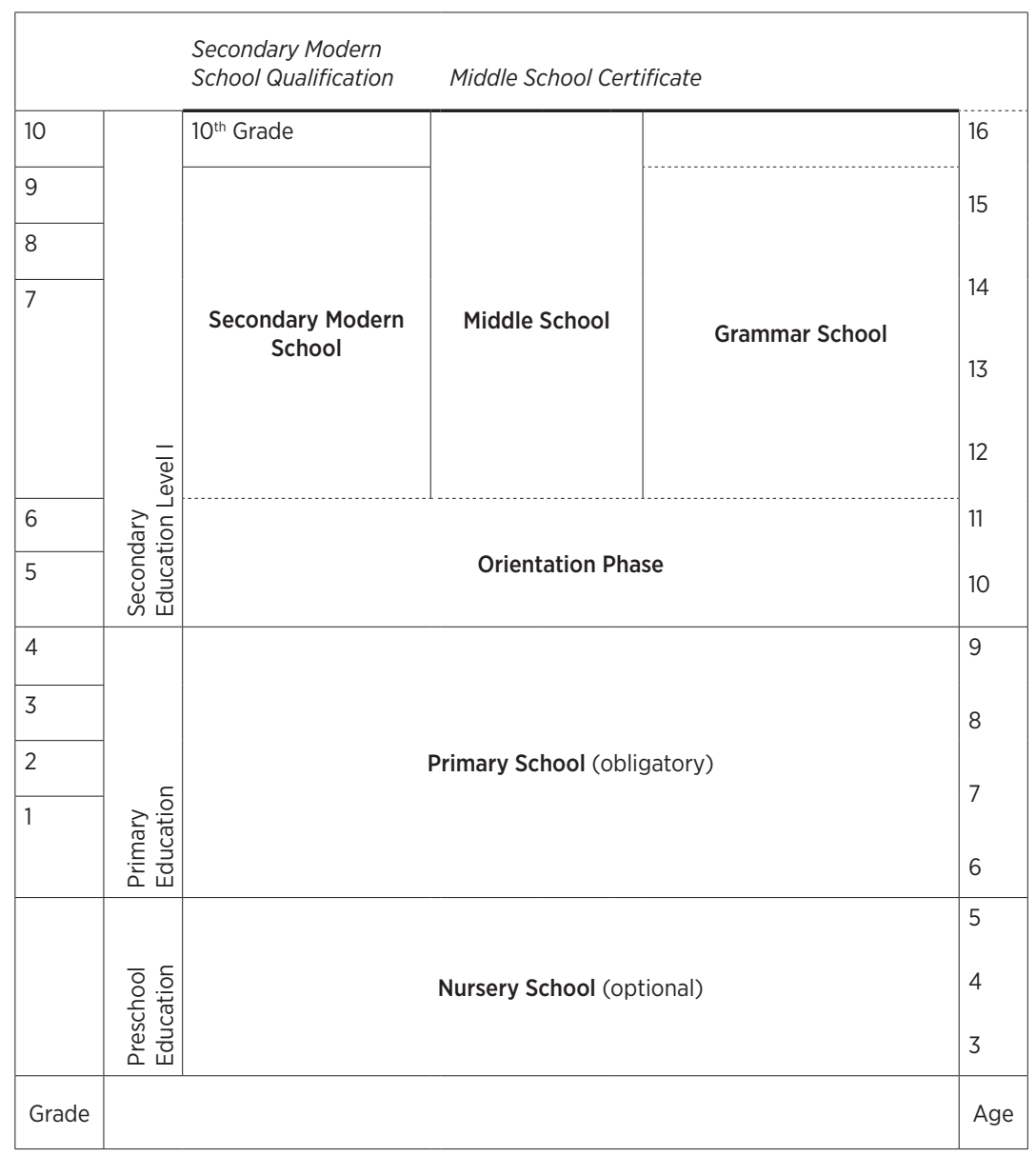

Figure 1. Germany's Educational System (KMK, 2013)

In Germany, children have to go to school from the year in which they turn six until they have completed at least nine (in some federal states ten) years of schooling. Children attend primary school for four (sometimes six) years before they move on to a secondary school. The choice of the secondary school is subject to the child's performance in primary school. Depending on the form of secondary school, children are able to achieve different qualifications determining their further education (KMK, 2013).

The continuation presents a survey of general concepts of (high) ability in Germany, followed by a discussion of special talent-support activities in Germany and its different federal states. The conclusion includes a summary of the strengths, weaknesses, opportunities and threats of gifted education in Germany and its federal states based on a "SWOT analysis". 


\section{General Measures of Gifted Education and Talent Support in Germany}

Ability is understood to denote an individual's aptitude for certain achievements, whereas high ability refers to an individual's aptitude potential for outstanding achievements (Heller, 2000). Weinert (2000) considers learning the decisive mechanism in the transformation of high ability into excellent achievements, with personality factors as well as environmental influences having a significant bearing on the learning process. These factors also have an impact on learning and developmental processes, and must therefore be taken into account when dealing with gifted and talented children with excellent achievements, as well as with those with learning difficulties. In concrete terms, these impact factors, which form the foundations for outstanding achievements but may also be possible causes for underachievement, are of prime importance. They arise from both positive and negative characteristics and from the interactions of factors inherent in the child, as well as from external environmental factors, which are also described in the various theories of ability. "The Munich Model of Giftedness" (Heller et al., 2005), which was originally developed in Bavaria but now applies to all federal states, may serve as an example. It comprises non-cognitive personality characteristics (e.g., achievement motivation, working attitude) as well as environmental factors (e.g., school climate, quality of instruction).

Despite the differences within the group of highly able children, they share certain characteristics, i.e., high speed of learning, great depth and complexity of understanding, intelligent organisation of knowledge, high metacognitive competences and, to some extent, remarkable creative abilities (Weinert, 200o). Individual adjustment of these characteristics forms the basis of selfregulated lifelong learning, which is confirmed by checklists on the characteristics of highly able children (BMBF, 2003). Apart from the characteristics of learning and thinking, self-regulated lifelong learning covers aspects such as working attitude, interests, and features of social behaviour. In particular, the characteristics of working attitude and interests reveal high motivationalvolitional competences for achievement motivation and special metacognitive competences for self-regulation as decisive conditions for self-regulated learning in ability promotion. This applies first and foremost to talented children with excellent achievements, whereas high-ability children with learning difficulties are primarily in need of special instruction in adequate strategies of self-regulated learning in order to become capable of using special forms of self-regulated learning efficiently. This underlines the need for essential learning resources of the learner and appropriate educational resources of the 
environment according to the "Actiotope Model of Giftedness" (Ziegler, 2005).

Regarding the models of gifted education and talent support, it is common to draw a distinction between forms of acceleration (i.e., accelerated learning) and enrichment (i.e., in-depth learning). These can primarily be derived directly from the characteristics of highly able children, because accelerated forms of learning require a fast processing speed, whereas in-depth learning requires a high processing capacity. These two basic concepts are, however, closely related, particularly since forms of acceleration are likely to create space for the development of enrichment (Hany \& Heller, 1996). Combinations of the two promotion principles will, above all, often be employed in the classroom because of the special requirements of the promotion of gifted and talented children. Such combinations are, therefore, frequently described as an independent promotion category for highly able children (BMBF, 2009). In general, forms of acceleration allow the regular curriculum to start and finish earlier, or to be completed faster (i.e., curriculum compacting), which, in most cases, entails a shortened time of schooling. Using the principle of enrichment, on the other hand, makes it possible to make additions and extensions to the regular curriculum (i.e., parallel curriculum), or to delve deeper into the curriculum without reducing the overall time of schooling.

Table 1. Models of Gifted Education and Talent Support in Germany (BMBF, 2009)

\begin{tabular}{|c|c|c|c|c|c|}
\hline \multicolumn{2}{|c|}{ Acceleration } & \multicolumn{2}{|c|}{ Enrichment } & \multicolumn{2}{|c|}{$\begin{array}{l}\text { Mixed Forms } \\
\text { (Acceleration/Enrichment) }\end{array}$} \\
\hline ० & Early School Entrance & $\circ$ & Individualisation & $\circ$ & Intensive Courses \\
\hline ० & $\begin{array}{l}\text { Mixed Age Groups and } \\
\text { Flexible School Entrance }\end{array}$ & ○ & $\begin{array}{l}\text { Extracurricular } \\
\text { Workshops }\end{array}$ & $\circ$ & $\begin{array}{l}\text { Accelerated Classes } \\
\text { ("Schnellläufer" or }\end{array}$ \\
\hline \multirow[t]{3}{*}{$\circ$} & Grade-Skipping & ○ & Additional (Advanced) & & “D-Zug-Klassen”) \\
\hline & (individually or in & & Courses & \multirow[t]{2}{*}{$\circ$} & Schools with Bilingual \\
\hline & groups) & 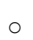 & Nationwide Academies \& & & Classes \\
\hline \multirow[t]{4}{*}{ ○ } & Participation in Classes & & Competitions & \multirow[t]{2}{*}{$\circ$} & Schools/Classes for \\
\hline & & $\circ$ & $\begin{array}{l}\text { Cooperation with } \\
\text { Universities and Business }\end{array}$ & & $\begin{array}{l}\text { Gifted and Talented } \\
\text { Learners }\end{array}$ \\
\hline & & & Companies & \multirow[t]{2}{*}{$\circ$} & \multirow{2}{*}{$\begin{array}{l}\text { Participation in } \\
\text { University Courses } \\
\text { (Junior Studies) }\end{array}$} \\
\hline & & $\circ$ & $\begin{array}{l}\text { Student Exchange } \\
\text { Programmes }\end{array}$ & & \\
\hline
\end{tabular}

With regard to the question of whether and how gifted education can be put into practice on the basis of a classroom that aims to identify competences, specific concepts in the area of talent support have not yet been developed. Against this background, the "Schoolwide Enrichment Model" (SEM) or the 
"Autonomous Learner Model" (ALM), which originate from the USA but are increasingly employed in Germany, are frequently mentioned as instruments of gifted education. These concepts share the feature that they primarily make use of forms of self-regulated lifelong learning (e.g., individualised free and projectbased work) for talent support in schools. This appears to be appropriate because self-regulated forms of research-based learning require enhanced (meta) cognitive competences, in which highly able learners excel (Weinert, 2000).

In connection with forms of self-regulated lifelong learning in gifted education and talent support, the "Schoolwide Enrichment Model" (Renzulli \& Reis, 1997) is very common in Germany. Its “Type-I Enrichment” enables learners to gain access to their own individual interests via general exploratory activities. Its “Type-II Enrichment" conveys group training activities, e.g., for self-regulated lifelong learning, and in its "Type-III Enrichment" children carry out individual and small group investigations of real problems (i.e., via pull-out). The "Autonomous Learner Model” (Betts \& Kercher, 1999) employs a similar concept in federal states. Its graded activities aim to ultimately lead to self-regulated and thus lifelong learning. Within this model, "Dimension I: Orienting" comprises the basics of the ability concept and the programme design, followed by "Dimension II: Individual Development", which imparts the competences of self-regulated learning. "Dimension III: Enrichment" comprises extracurricular content with possibilities of differentiation for the learner. In "Dimension IV: Seminars", the learners investigate, present and evaluate different topics cooperatively, whereas in "Dimension V: In-Depth Studies" the learners devote themselves, alone or in small groups, to independent long-term projects selected from their areas of interest (i.e., via grouping).

The continuation of this section presents various aspects and measures of gifted education and talent support in Germany that apply cross-border to all federal states.

\section{Associations}

Various associations show a huge commitment throughout Germany with regard to advising and promoting gifted and talented children. Here, the Karg-Foundation and the "Association for Education and Giftedness" ("Bildung \& Begabung") are highlighted. Both associations promote support for gifted persons and the exchange of information on giftedness, as well as encouraging cooperation between different institutions. In addition, various parents' associations exist, such as the "German Association for Gifted Children" ("Deutsche Gesellschaft für das hochbegabte Kind"), the "Society for Gifted Education" ("Hochbegabtenförderung e.V."), the "Association for Talent Research and 
Gifted Education" ("Arbeitskreis Begabungsforschung und Begabtenförderung e.V."), "Supporting the Gifted" ("Hochbegabtenförderung e.V."), and the network "Mensa in Germany" ("Mind - Mensa in Deutschland e.V."). There are also several associations focusing on different forms of talent, such as the "International Academy of Music for Supporting the Gifted in Germany" ("Internationale Musikakademie zur Förderung Hochbegabter in Deutschland”), which supports musically talented individuals.

\section{Foundations}

In addition to the major associations of gifted education and talent support in Germany mentioned above, perspectives of talent discovery in Germany are evident beyond the borders of the federal states (Heller \& Ziegler, 2007). These include foundations that support highly able children. Apart from the contributions of the "Karg-Foundation for Gifted Education" ("Karg-Stiftung für Hochbegabtenförderung") and the "Association of Foundations for Sciences in Germany" (Stifterverband für die Deutsche Wissenschaft"), there is a large number of other institutions. Among these are various political foundations, foundations of the Catholic ("Cusanuswerk") and Protestant Churches ("Evangelisches Studienwerk Villigst"), as well as of the government ("Deutschlandstipendium"), which generally support talented university students, although a number of scholarships for pupils can also be found. The "German Scholarship for Pupils" ("Deutsches Schülerstipendium") of the Roland-Berger-Foundation is particularly noteworthy, as it supports highly able students from underprivileged families. Furthermore, the "Joachim Herz Foundation" ("Joachim Herz Stiftung") and the "Robert Bosch Foundation" ("Robert Bosch Stiftung") support the pupils' scholarship "Intelligence Wins" ("Grips gewinnt"), which is also awarded to talented pupils from underprivileged backgrounds.

\section{Academies and Contests}

Ability promotion beyond the borders of the German federal states is further comprised of federal school competitions and academies for talent support. The "Association for Education and Giftedness" ("Bildung \& Begabung") organises a large number of different contests covering maths or foreign languages. In addition, various academies are offered, such as the "German Pupils Academy" ("Deutsche SchülerAkademie"), the "German Junior Academies" ("Deutsche JuniorAkademien"), the "Talent Academy", and the "Role Model Academy" ("VorbilderAkademie"). The "German Pupils Academy" is constituted of a summer camp where talented pupils work cooperatively on various academic projects. This format serves as a role model for other forms of support 
offered by the Association for Education and Giftedness. A further contest is the "German Contest for Young Scientists", which is aimed at pupils gifted in maths, science and information technologies. Children aged 4-21 are eligible to participate in this contest and to conduct a research project focusing on a research question of their interest (Jugend forscht, 2014). The "Kangoroo Contest" ("Känguruh Wettbewerb") challenges pupils' mathematical abilities and aims to arouse their interest in maths (Känguru der Mathematik, 2014). In addition to the contests and academies presented above, there are many other competitions covering all subject areas. As well as special contests and academies, the majority of German universities offer courses of study for talented children, who are able to attend classes and take exams that can be credited to a later degree.

\section{Conferences}

Various conferences on gifted education and talent support are of significance beyond the borders of federal states. Here, "Münster's Congress of Education" ("Münsterscher Bildungskongress") on talent research and gifted education, hosted by the International Centre for the Study of Giftedness, is particularly important. This congress takes place every three years and was linked to the $13^{\text {th }}$ ECHA Conference in 2012. In addition, there is the annual ECHA-Day ("ECHA-Tag”), which facilitates exchange and networking opportunities for teachers.

\section{Qualifications for Educators}

With regard to teacher education, there are a number of special further training programmes of note. Firstly, the European Council for High Ability (ECHA) offers a variety of courses focusing on different target groups in cooperation with the International Centre for the Study of Giftedness at the University of Münster. The ECHA Diploma "Specialist in Gifted Education" is aimed at teachers, while the ECHA Certificate "Specialist in Preschool Gifted Education" covers preschool teachers, and the qualification "Specialist in Coaching the Gifted" appeals to voluntary counsellors. Another form of special education can be found at the University of Education Karlsruhe, which offers an extra occupational master's degree in "The Integrative Support of Giftedness and the Gifted” ("Integrative Begabungs- und Begabtenförderung"). This degree is taught in cooperation with the University of Applied Sciences and Arts Northwestern Switzerland, and is aimed at teachers, educators and those responsible for supporting talents. The University of Leipzig also teaches a master's degree in "Studies in Abilities and Development of Competences", which enables graduates to work in counselling centres and institutions supporting giftedness. In addition, preschool teachers 
and educators can qualify as an "Educator for the Gifted" ("Begabtenpädagoge") after completing a further education course offered by the University of Applied Sciences for Social Work, Education and Nursing Dresden and by the University of Rostock. An additional special education programme can be found at the institute for further education "eVOCATIOn". Following the approach of accepting and supporting each student's individual abilities, educators are qualified to identify, individually support and accompany students with high abilities (Karg-Stiftung, 2014b). In terms of special further training, one more cooperation should be mentioned. In January 2014, the "Department for Giftedness" was established at the Psychologische Hochschule Berlin in cooperation with the Karg-Foundation. Aiming at offering further education programmes for promoting abilities, the department cooperates with independently operating institutions throughout Germany (Psychologische Hochschule Berlin, 2014).

\section{Special Means of Gifted Education and Talent Support in German Federal States}

\section{The Education Act and the Teacher Training Act}

Table 3 (below) shows which German federal states explicitly include ability promotion in their education and teacher training acts (Fischer, 2014). The table indicates that nearly all German federal states explicitly include gifted education in their education acts, whereas almost no federal states include talent support in their teacher training acts.

Table 2. Talent Support in Germany's Education and Teacher Training Acts (Fischer, 2014)

\begin{tabular}{clll}
\hline German & Federal State & Education Act & Teacher Training Act \\
\hline 1. & Baden-Württemberg & Yes & Yes \\
2. & Bavaria & No & No \\
3. & Berlin & Yes & No \\
4. & Brandenburg & Yes & No \\
5. & Bremen & No & No \\
6. & Hamburg & Yes & No \\
7. & Hesse & Yes & No \\
8. & Mecklenburg-Western Pomerania & Yes & No \\
9. & Lower Saxony & Yes & No \\
10. & North-Rhine Westphalia & Yes & No \\
11. & Rhineland-Palatinate & No & Yes \\
12. & Saarland & No & No \\
13. & Saxony & Yes & No \\
14. & Saxony-Anhalt & Yes & No \\
15. Schleswig-Holstein & Yes & No \\
16. & Thuringia & Yes & No \\
\hline
\end{tabular}


With regard to the comparison of the individual federal states, the "Report on Talent Promotion in German Schools" (Holling et al., 2004) provides important evidence of the large-scale realisation of the talent discovery and promotion models outlined above. This is complemented by a description of the current models of ability promotion in the federal states. The information is generally retrieved from Bildung \& Begabung (2014) and Karg-Stiftung (2014a, 2008), with the use other sources being specifically indicated.

Table 3. Special Activities of Talent Support and Gifted Education in Germany's Federal States

\begin{tabular}{|c|c|c|}
\hline \multicolumn{2}{|c|}{ German Federal States } & \multirow{2}{*}{$\begin{array}{l}\text { Special Activities } \\
\text { Special Schools \& Classes, Counselling \& Research } \\
\text { Centres, Teacher Training }\end{array}$} \\
\hline 1. & Baden-Württemberg & \\
\hline 2. & Bavaria & Special Classes, Counselling \& Research Centres \\
\hline 3. & Berlin & Accelerated Classes, School Network, Special Schools \\
\hline 4. & Brandenburg & Special Schools \& Classes, Teacher Training \\
\hline 5. & Bremen & Ability Grouping, Counselling Centres \\
\hline 6. & Hamburg & $\begin{array}{l}\text { School Network, Counselling Centre, School Award, } \\
\text { Special Classes }\end{array}$ \\
\hline 7. & Hesse & $\begin{array}{l}\text { Special School, School Award, Counselling \& Research } \\
\text { Centres }\end{array}$ \\
\hline 8. & $\begin{array}{l}\text { Mecklenburg-Western } \\
\text { Pomerania }\end{array}$ & Special Schools \& Classes, Study Days \\
\hline 9. & Lower-Saxony & Special Classes, School Network \\
\hline 10. & North-Rhine Westphalia & $\begin{array}{l}\text { Special Classes, Counselling \& Research Centres, Teacher } \\
\text { Trainings, School Award, School Network }\end{array}$ \\
\hline 11. & Rhineland-Palatinate & $\begin{array}{l}\text { Special Schools \& Classes, Grouping Activities, } \\
\text { Counselling \& Research Centres }\end{array}$ \\
\hline 12. & Saarland & Counselling Centre, Study Days \\
\hline 13. & Saxony & $\begin{array}{l}\text { Special Schools, Counselling Centre, Teacher Training, } \\
\text { School Network }\end{array}$ \\
\hline 14. & Saxony-Anhalt & $\begin{array}{l}\text { Special Schools, Grouping Activities, School Networks, } \\
\text { Counselling Centre }\end{array}$ \\
\hline 15. & Schleswig-Holstein & $\begin{array}{l}\text { Grouping, School Network, Counselling \& Research } \\
\text { Centre }\end{array}$ \\
\hline 16. & Thuringia & Special Schools \& Classes, Camps, Counselling Centres \\
\hline
\end{tabular}

\section{Baden-Württemberg}

With regard to gifted education and talent support, Baden-Württemberg offers two special schools, one of which is a state school and the other a private school. At the "State Boarding Schools for Gifted Children Schwäbisch Gmünd" ("Landesgymnasium für Hochbegabte Schwäbisch Gmünd") highly able children enter school either in year 7 or year 10. This school also comprises a counselling centre. The private "Leonardo da Vinci-Gymnasium Neckargemünd" 
has a particular focus on science classes; therefore, children attend additional classes in biology, chemistry and physics from year 5 to 10. In addition, the subject computer science is also taught. There are also 15 grammar schools that offer special classes for highly able children in Baden-Württemberg. Following the principle of acceleration, learning takes place at a higher pace in order to offer additional learning opportunities (enrichment) without increasing the overall number of lessons per week. These lessons are usually offered in cooperation with universities and companies. An evaluation of this programme, as well as a similar programme in Bavaria ("PULSS-Studie"), revealed that these lessons lead to higher learning efficiency and a positive social and academic self-concept, as well as increased enjoyment in thinking (Preckel et al., 2012).

\section{Bavaria}

In Bavaria, gifted and talented children are able to attend special classes, which are provided at eight different schools and which allow the children to participate in additional lessons supporting content knowledge as well as cognitive, emotional and social skills. Talent classes are also offered at some middle schools, which can only be found in Bavaria (e.g., Deutschhaus Gymnasium Würzburg, Maria Theresia Gymnasium München). Here, the children’s abilities are challenged and supported, and additional classes as well as special language exams are established. Research and counselling centres are affiliated to various universities (e.g., Julius-Maximilians-University Würzburg, Ludwig-Maximilians-University Munich and University Nuremberg-Erlangen) (Bayerisches Staatsministerium für Bildung und Kultus, Wissenschaft und Kunst, 2014).

\section{Berlin}

There are various approaches to gifted education and talent support in Berlin. At primary school level, a network of 13 primary schools offers additional lessons and special classes. A number of secondary schools (13 grammar schools overall) provide special classes that skip year 8 , so that the overall time at school is reduced. Furthermore, accelerated lessons can be found at some schools, which save six weeks of lessons per year in order to facilitate additional lessons and special projects. There are also special schools that focus on and support specific talents such as sport, music or languages. Several schools further establish special classes focusing on supporting and challenging mathematically talented children (e.g., Herder-Gymnasium Charlottenburg and Heinrich-Hertz-Gymnasium Friedrichshain). Finally, regional groups of gifted children ("Regionale Begabtengruppen"), which consist of one grammar school and a number of primary schools, offer enrichment programmes covering 
methodological aspects and learning strategies in homogeneous groups (Senatsverwaltung für Bildung, Jugend und Wissenschaft, 2014).

\section{Brandenburg}

Brandenburg's gifted education and talent support consists of $35 \mathrm{sec}$ ondary schools providing so-called "Performance and Talent Classes" ("Leistungs- und Begabungsklassen - LuBK”), which focus on various subjects (e.g., languages, music, maths) or different forms of talent. In addition, it is possible to leave primary school after four instead of six years in order to attend these special classes. Some schools also offer a so-called "revolving door model" following the Schoolwide Enrichment Model, which allows children to participate in individual lessons at a higher level.

\section{Bremen}

Bremen offers gifted education and talent support in various ways. At primary school level, talented children are able to attend "special projects" for which they are allowed to leave their regular lessons. Each project group consists of 12 children who collaboratively work on a particular topic and achieve self-regulated learning strategies. Apart from that, Bremen usually attempts to support different talents in an inclusive setting. Therefore, a pilot project has been developed that involves the cooperation of a primary and a secondary school. Individual talents are diagnosed and supported in order to achieve optimal results in performance. This project is supported by the University of Bremen and the Karg-Foundation (Pfälzer Weg, 2012). There are a number of regional counselling and support centres in Bremen as well (e.g., ReBUZ). Projects provided by external institutions are a further characteristic of gifted education in Bremen. Apart from regular opportunities to study at the universities of Bremen, the German Aerospace Centre and the Centre for Marine Environmental Science both offer special projects for talented children. Here, children are able to participate in experiments and conduct research projects on their own.

\section{Hamburg}

Gifted education and talent support in Hamburg are covered by a network called "Butterflies" ("Schmetterlinge"), which is a cooperation of primary schools developing talents. From 2004 to 2007 and from 2010 to 2012, schools participated in this project and qualified as schools competent to diagnose and support gifted children. These schools acquire a seal of quality. Secondary schools are also involved in this network, which is coordinated by the 
counselling centre "BbB" ("Beratungsstelle besondere Begabungen"). In addition, several schools in Hamburg offer special classes for talented children. In some cases, so-called "skipping classes" ("Springerklassen") can also be found. Highly able children can also attend additional classes on particular topics (enrichment projects), either as part of a revolving door model (parallel to regular lessons) or in addition to their regular lessons. It is also possible to participate in lessons of particular subjects at a higher level (acceleration). Finally, some primary schools focus specifically on particular aspects (e.g., bilingual and immersion schools or sport classes).

\section{Hesse}

There are a number of aspects to Hesse's approach to gifted education and talent support. The federal state awards a so-called "Seal of Quality Giftedness" ("Gütesiegelschulen") to those schools whose school programmes focus on promoting gifted children, diagnosing talents and counselling parents. The intention in Hesse is that highly able children stay and learn in their regular classes. There is only one special grammar school (i.e., Boarding School Schloss Hansenberg), which is supported by the federal state as well as by individual companies. Schloss Hansenberg supports scientifically, mathematically and politically talented children. Moreover, there are various counselling centres as well as school psychologists. The special counselling and research centre "BRAIN", which focuses exclusively on giftedness, is affiliated to the Marburg University. In addition, the centre for giftedness in Frankfurt/Main serves as a counselling centre and offers different extracurricular classes (e.g., chess, art, maths, research projects, etc.). Finally, the foundation "Houses of Little Researchers" (Stiftung "Haus der kleinen Forscher") should also be mentioned. It establishes further education programmes for teachers in order to develop and support children's interest in science and technology, and to generally kindle their interest in conducting research. Here, programmes start as early as at nursery school and are continued in primary school.

\section{Mecklenburg-Western Pomerania}

In Mecklenburg-Western Pomerania, the model for supporting gifted and talented children covers participation in "study days". Highly able children have an opportunity to attend courses of their choice on one day every two weeks. These days are organised by school boards. At secondary school level, special classes are installed (one in each district) that support giftedness by offering special courses in maths, science and foreign languages. The participating schools also serve as centres for diagnosing and counselling giftedness. There 
are also special schools, such as sport or music schools, while some schools focus exclusively on high ability (e.g., CJD Christopherusschule Rostock and Boarding School Schloss Torgelow).

\section{Lower-Saxony}

Regarding gifted education and talent support, Lower-Saxony includes school networks for accompanying and guiding highly able children. These networks consist of nursery as well as primary and secondary schools, and strengthen the cooperation and exchange of information between the different types of school. Special classes for gifted children can only be found at the "CJD Christopherusschule Braunschweig". In addition, a number of schools offer the option of attending individual classes in particular subjects at a higher level (acceleration).

\section{North Rhine-Westphalia}

There are various approaches to ability promotion in North RhineWestphalia. One component is the quality seal (former "Quality Seal Individual Support", now "Network Future Schools North Rhine-Westphalia"), which is awarded to schools that focus on supporting highly able children by offering special training for their teachers, and by applying differentiating teaching methods. The award is connected to a network that promotes giftedness in North Rhine-Westphalia. This network qualifies schools for supporting gifted children, sets goals for supporting the gifted in the process of school development, and builds regional networks for cooperation in the process of supporting giftedness. In addition, the "Foundation for Education to Promote the Gifted" ("Stiftung Bildung zur Förderung Hochbegabter") awards the "School Prize for Gifted Education" to those schools diagnosing, supporting and counselling highly able children. Furthermore, there are various research and counselling centres (the International Centre for the Study of Giftedness, Hochbegabtenzentrum Rheinland and the Competence Centre Begabtenförderung Düsseldorf). The International Centre for the Study of Giftedness is a cooperation facility of the Universities of Münster, Nijmegen and Osnabrück. It also cooperates with the Statewide Competence Centre for Individual Support, which is promoted by the federal state. Based on the "Schoolwide Enrichment Model" and the "Autonomous Learner Model", this centre has developed the so-called "Challenge and Support Project", which (primary and secondary) schools often realise for independent projects of small learner groups or advanced studies in self-determined projects, which are included in and systematically employed as a means of teaching self-regulated and research-based learning (Fischer \& 
Fischer-Ontrup, 2012). While it is generally intended that highly able children are taught in integrative or inclusive settings and in the regular classroom (particularly in primary schools), the CJD Chistopherusschule Königswinter provides special classes that support gifted children.

\section{Rhineland-Palatinate}

Rhineland-Palatinate offers early support for gifted and talented children and covers the cooperation of nursery and primary schools. Here, gifted children are able to participate in an inter-year project once a week, which is not limited to a particular subject. Working on a topic of the children's choice represents a second constituent of this "research day". The tasks studied in the project are taken into regular classes in order to ensure a connection between the project and regular lessons. In addition, special classes ("BEGYS-classes") at grammar schools are offered. These allow highly motivated and gifted children to reduce their overall time at school, as the whole class skips year 9. There are also some schools that focus on particular subjects (e.g., bilingual classes, music education, etc.). In addition, four special schools for supporting highly able children have been affiliated to secondary schools (Max von Laue-Gymnasium Koblenz, Auguste-Viktoria-Gymnasium Trier, Heinrich Heine-Gymnasium Kaiserslautern and Otto-Schott-Gymnasium Mainz-Gonsenheim). RhinelandPalatinate also includes the "Children College" ("Kinder-College") in Neuwied, which is an extracurricular institution offering classes on all subject areas on the weekends. It is funded by the federal state as well as by donations and fees for the classes. The International Centre for the Study of Giftedness has evaluated this college and confirmed its quality and efficiency (Kinder-College, 2014). Finally, there are various competence centres for giftedness incorporated into three school psychological counselling centres, as well as one counselling centre that cooperates with the CJD Trier.

\section{Saarland}

In Saarland, highly able children can attend additional classes on interdisciplinary topics in parallel or in addition to their regular classes. This programme aims at adding content to the regular curriculum, while the focus is mainly on achieving learning strategies and social competences. There is also a counselling centre ("IQ XXL Beratungsstelle Hochbegabung") that organises different projects, as well as offering diagnosis, counselling and support to high-ability children and their parents. 


\section{Saxony}

In terms of gifted education and talent support, Saxony has two special schools for gifted children: one primary school (Grundschule Josephine Dresden) and one secondary school (Sächsisches Landesgymnasium Sankt Afra). These schools offer individual learning contracts, contests and additional projects for highly able children. At Sankt Afra, children take three advanced courses (Leistungskurse), study three foreign languages, and write an academic paper. Apart from the special schools that support talented children in general, some schools (“\$4 Gymnasium”) focus on particular talents (e.g., science, languages, music, art and sport). Several primary schools offer particular projects for supporting gifted children, who can attend individualised lessons and are enabled to apply their talents and to cooperate with their classmates. In Saxony, there are also a number of networks of different schools. The network "GIFted" covers integrative support by offering individualised learning opportunities and projects at 22 different secondary schools. This cooperation also includes an exchange between teachers. It is supported by the University of Leipzig and affiliates a counselling centre, while a second counselling centre for giftedness $(\mathrm{BzB})$ is installed and supported by the federal state.

\section{Saxony-Anhalt}

In Saxony-Anhalt, ten different boarding schools focusing on a range of talents (sport, maths and science, language, arts and music) can be found. Here, additional lessons on the promoted subject are provided, while other lessons also relate to it. Moreover, there are extracurricular projects offered that allow highly able children to deepen and broaden their content knowledge of particular subjects. Saxony-Anhalt is further characterised by its networking schools, consisting of six primary and eight secondary schools, which are awarded a seal of quality for participating. These collaborations develop differentiating and supportive lesson concepts as well as counselling parents, teachers and students. Saxony-Anhalt's counselling centre "LISA's Supporting Giftedness" ("Hochbegabungsförderung" des LISA) coordinates this network.

\section{Schleswig-Holstein}

In Schleswig-Holstein, a number of different approaches to gifted education and talent support can be found. One constituent is school networks organising additional classes for gifted children to conduct projects of explorative learning. Highly able students are also offered individual learning schedules from primary school onwards, which enables continuity in support and diagnosis. The counselling centre "MIND" ("Motivations- and Intelligenzdiagnostik") 
is affiliated to the University of Kiel. In addition, individual teachers provide counselling services in cooperation with the government. Another characteristic of ability promotion in Schleswig-Holstein is the mentor project "Peer to Peer". Older gifted children (from the age of 14) serve as mentors for younger highly able children, with the mentors attending a special training on aspects of giftedness. This project is offered at eleven secondary schools, which also serve as competence centres ("Competence Centres for Supporting the Gifted in Secondary Schools"), as they have developed various concepts for supporting gifted children, as well as providing advice and guidance to other schools. There are also five competence centres at nursery and primary school level. Finally, schools that offer particular projects for supporting giftedness are classified as "Schools Including Support of Giftedness" ("SH i B - Schule inklusive Begabtenförderung”).

\section{Thuringia}

Gifted education and talent support in Thuringia are covered by a range of extracurricular courses for primary school children. The classes, which are organised as camps lasting for a couple of days, take place parallel to regular lessons, from which the participating children are allowed be absent. At secondary school level, some schools offer special classes on different subjects (maths and science, music, language and sport). Another form of ability promotion in Thuringia is a group of schools of mathematics (Jena, Erfurt and Ilmenau), which also include a regional counselling centre.

Overall, the presentation above shows that Germany embraces a diverse system of talent support, including quite different forms of measures. While some activities, such as various enrichment projects, can be found in several states, there are also means that are specific to one particular state. Concerning special activities in gifted education and talent support (Table 4), it can be said that south and east German federal states usually include schools for highly able children, whereas north and west German federal states rely exclusively on regular schools and classes. This can often be traced back to the ruling political party in the individual states. Furthermore, throughout Germany, talented children are able to start school before the regular school age, as well as having the possibility to skip a class. The large range of measures offers abundant opportunities for the future of supporting talents in Germany. By evaluating the concepts applied and by networking more closely, the states could benefit from each other, which could lead to the development of a general national strategy of talent support. 


\section{Conclusion}

In summary, Germany and its federal state structure has advantages as well as disadvantages with regard to gifted education and talent support. The present paper concludes with a "SWOT analysis" covering the strengths, weaknesses, opportunities and threats of the German activities. In a second step, aspects of the SWOT analysis are combined in order to evaluate which aspects can serve to improve gifted education and talent support in Germany. All of the aspects mentioned serve the purpose of systematising; however, it should be remembered that strengths can easily turn into weaknesses and vice versa.

Table 4. SWOT Analysis of Gifted Education and Talent Support in Germany

\begin{tabular}{|c|c|c|}
\hline $\begin{array}{l}\text { SWOT } \\
\text { Analysis }\end{array}$ & Strengths & Weaknesses \\
\hline Opportunities & $\begin{array}{l}\text { The diverse systems of gifted } \\
\text { education and talent support } \\
\text { represent a noteworthy strength. } \\
\text { They include a range of contests } \\
\text { and academies, a complex system } \\
\text { of foundations (e.g., the Karg- } \\
\text { Foundation focusing explicitly on } \\
\text { giftedness and offering different } \\
\text { forms of support) and counselling } \\
\text { centres, some of which are affiliated } \\
\text { to research centres. In addition, } \\
\text { Germany is an economically strong } \\
\text { country with many resources } \\
\text { available. }\end{array}$ & $\begin{array}{l}\text { The large number of various } \\
\text { measures related to gifted education } \\
\text { in the different federal states is a } \\
\text { disadvantage, as there is a lack of a } \\
\text { common national strategy of talent } \\
\text { support, which is also due to a lack } \\
\text { of networking. Furthermore, the } \\
\text { measurements depend strongly on the } \\
\text { ruling political party in the individual } \\
\text { states. Another significant weakness } \\
\text { is that giftedness still does not form } \\
\text { an integral part of various discussions, } \\
\text { such as the debate on inclusion or on } \\
\text { the results of comparative studies such } \\
\text { as PISA (2012, 2014), PIRLS (2012) or } \\
\text { TIMSS (2012). }\end{array}$ \\
\hline Threats & $\begin{array}{l}\text { The German concept of gifted } \\
\text { education has numerous } \\
\text { opportunities for further improving } \\
\text { its models. The states can benefit } \\
\text { from each other's experiences } \\
\text { and expertise by networking and } \\
\text { exchanging ideas and information } \\
\text { on their applied concepts of ability } \\
\text { promotion. Moreover, focusing not } \\
\text { only on less able but also on highly } \\
\text { able children is a promising aspect. }\end{array}$ & $\begin{array}{l}\text { The threats that the German system } \\
\text { faces include the fact that potentials } \\
\text { are not diagnosed and that there is } \\
\text { too much focus on deficits. Particularly } \\
\text { with regard to the concept of inclusion, } \\
\text { there is a danger of labelling, and } \\
\text { of the term inclusion only being } \\
\text { associated with less able children. }\end{array}$ \\
\hline
\end{tabular}


Table 5. SWOT Analysis II of Gifted Education and Talent Support in Germany

\begin{tabular}{|c|c|c|}
\hline $\begin{array}{l}\text { SWOT } \\
\text { Analysis II }\end{array}$ & Strengths & Weaknesses \\
\hline Opportunities & $\begin{array}{l}\text { Germany's economic strengths } \\
\text { should be used to invest in } \\
\text { supporting gifted education and } \\
\text { talent support. This could cover } \\
\text { all forms of supporting gifts and } \\
\text { talents. It could also be used to } \\
\text { concentrate on potentials rather } \\
\text { than on deficits. }\end{array}$ & $\begin{array}{l}\text { The diversity of models could be used } \\
\text { for building a national strategy of } \\
\text { gifted education and talent support } \\
\text { in Germany. This would require more } \\
\text { networking of the federal states as well } \\
\text { as their counselling and research centres. } \\
\text { Furthermore, the focus on less able } \\
\text { children and their deficits needs to be } \\
\text { replaced by focusing more attention on } \\
\text { potentials. }\end{array}$ \\
\hline Threats & $\begin{array}{l}\text { The threats of potentials not being } \\
\text { fully exploited can be avoided by } \\
\text { using Germany's economic strengths } \\
\text { to invest in new and diverse } \\
\text { approaches to gifted education and } \\
\text { talent support. These should apply } \\
\text { to the individual as well as to society } \\
\text { as a whole. }\end{array}$ & $\begin{array}{l}\text { Due to the lack of systematic } \\
\text { diagnostics, it is necessary to improve } \\
\text { the qualifications for identifying } \\
\text { potentials. This would diminish the } \\
\text { risk of failing to diagnose abilities and } \\
\text { potentials. } \\
\text { With regard to the discussion on } \\
\text { inclusion, ways of including highly able } \\
\text { children should also be considered, } \\
\text { in order to avoid putting too much } \\
\text { emphasis on the less able and their } \\
\text { deficits. }\end{array}$ \\
\hline
\end{tabular}

Overall, gifted education and talent support increasingly form a more integral part of educational, societal and political discussions in Germany. New insights gained through special research on giftedness and talent, as well as the large variety of measures for supporting gifted and talented children, lead to an improved understanding and appropriate concepts of ability promotion. Still, there are opportunities for further improvement, such as the need to distinguish between performance and potential. However, the Conference of the Ministers of Education and Cultural Affairs has recently launched an initiative that deals with this issue. By incorporating different associations and foundations, as well as research and politics, this initiative aims at developing a national strategy of gifted education and talent support in Germany. 


\section{References}

Bayerisches Staatsministerium für Bildung und Kultus, Wissenschaft und Kunst. (2014).

Begabtenförderung - Wie funktioniert das eigentlich? Retrieved 5 May 2014 from http://www.

km.bayern.de/schueler/lernen/foerderung/begabtenfoerderung.html

Betts, G., \& Kercher, J. K. (1999). Autonomous Learner Model. Optimizing Ability. Greeley.

Bildung \& Begabung (2014). Länder-Special. Retrieved 5 May 2014 from http://www.bildung-und-

begabung.de/begabungslotse/laender-special

Bos, W., Tarelli, I., Bremerich-Vos, A., \& Schwippert, K. (2012). IGLU 2011 Lesekompetenzen von

Grundschulkindern in Deutschland im internationalen Vergleich. Münster: Waxmann.

Bos, W., Wendt, H., Köller, O., \& Selter, Ch. (2012). TIMSS 2011. Mathematische und

naturwissenschaftliche Kompetenzen von Grundschulkindern in Deutschland im internationalen

Vergleich. Münster: Waxmann.

BMBF - Bundesministerium für Bildung und Forschung. (2003). Begabte Kinder finden und fördern.

Bonn.

$\mathrm{BMBF}$ - Bundesministerium für Bildung und Forschung. (2009). Begabte Kinder finden und fördern.

Bonn.

Fischer, C., \& Fischer-Ontrup, C. (2012). Self-Regulated Learning Strategies in Gifted Education and Teacher Training. In A. Ziegler, C. Fischer, H. Stoeger, \& M. Reutlinger (Eds.), Gifted Education as a Lifelong Challenge. Essays in Honour of Franz J. Mönks (pp. 303-314). Münster: LIT.

Fischer, C. (2014). Individuelle Förderung als schulische Herausforderung. Berlin: Friedrich-EbertStiftung.

Hany, E., \& Heller, K. (1996). Psychologische Modelle der Begabtenförderung. In F. E. Weinert (Ed.), Psychologie des Lernens und der Instruktion (pp. 477-503). München: Hofgrefe.

Heller, K. A. (200o). Einführung in den Gegenstandsbereich der Begabungsdiagnostik. In K. A.

Heller (Ed.), Lehrbuch Begabungsdiagnostik in der Schul- und Erziehungsberatung, ${ }^{\text {nd }}$ ed. (pp. 13-40).

Göttingen: Hans Huber.

Heller, K. A., Perleth, Ch., \& Tock, K. L. (2005). The Munich Model of Giftedness Designed to Identify and Promote Gifted Students. In R. J. Sternberg \& J. E. Davidson (Eds.), Conceptions of giftedness (pp. 147-170). New York: Cambridge University Press.

Holling, H., Preckel, F., Vock, M., \& Schulze Willbrenning, B. (2004). Schulische Begabtenförderung in den Ländern, Maßnahmen und Tendenzen. Bonn.

Jugend forscht (2014). Was ist Jugend forscht. Retrieved 22 May 2014 from http://www.jugendforscht.de/

Känguru der Mathematik (2014). Wettbewerbsbedingungen. Retrieved 22 May 2014 from http:// www.mathe-kaenguru.de/wettbewerb/

Karg-Stiftung (2008). Begabtenförderung in den Bundesländern. Erfolge und Herausforderungen. Frankfurt.

Karg-Stiftung (2014a). Länderdaten. Retrieved 5 May 2014 from http://www.fachportal- 
hochbegabung.de/bundeslaender/laenderdaten/

Karg-Stiftung (2014b). Weiterbildung und Studiengänge. Retrieved 22 May 2014 from http://www.

fachportal-hochbegabung.de/weiterbildung-anbieter/

Kinder-College. (2014). Kinder-College. Retrieved 5 May 2014 from http://www.kinder-college.de/

Klemm, K. (2013). Inklusion in Deutschland. Eine bildungsstatistische Analyse. Gütersloh:

Bertelsmann Stiftung.

Klieme, E., Artelt, C., Hartig, J., Jude, N., Köller, O., Prenzel, M., Schneider, W., \& Stanat, P. (2010).

PISA 2009. Bilanz nach einem Jahrzehnt. Münster: Waxmann.

KMK - Secretariat of the Standing Conference of the Ministers of Education and Cultural Affairs of the Länder in the Federal Republic of Germany. (2013). The Education System in the Federal Republic of Germany 2011/2012. Bonn.

Mönks, F. J., \& Pflüger, R. (2005). Schulische Begabtenförderung in Europa - Vergleichende Bestandsaufnahme und Ausblick. Bonn.

Pfälzer Weg (2012). Projekt (Hoch-)Begabung inklusiv. Retrieved 5 May 2014 from http://www.091. joomla.schule.bremen.de/index.php/konzept/heterogenitaet/23-projekt-hoch-begabung-inklusiv Preckel, F., Schneider, W., Stumpf, E., \& Ziegler, A. (2012). Projekt zur Evaluation der Begabtenklassen in Bayern und Baden-Württemberg. Laufzeit 2008-2012. Abschlussbericht. Würzburg, Trier,

Nürnberg.

Prenzel, M., Sälzer, Ch., Klieme, E., \& Köller, O. (Hrsg.) (2013). PISA 2012 Fortschritte und Herausforderungen in Deutschland. Münster: Waxmann.

Psychologische Hochschule Berlin. (2014). Arbeitsstelle Hochbegabung Berlin. Retrieved 22 May 2014 from http://www.psychologische-hochschule.de/arbeitsstelle-hochbegabung-berlin.html Renzulli, J. S., \& Reis, S. M. (1997). The schoolwide enrichment model: A how-to guide for educational excellence. Mansfield.

Senatsverwaltung für Bildung, Jugend und Wissenschaft. (2014). Regionale Begabtengruppen am Nachmittag. Retrieved 5 May 2014 from http://www.berlin.de/sen/bildung/foerderung/ begabungsfoerderung/regionale_begabtengruppen.html UNESCO. (1994). The Salamanca Statement and Framework for Action on Special Needs Education. Retrieved 21 August 2014 from http://www.unesco.org/education/pdf/SALAMA_E.PDF Weinert, F. E. (2000). Lernen als Brücke zwischen hoher Begabung und exzellenter Leistung. Vortrag gehalten anlässlich der zweiten internationalen Salzburger Konferenz zu Begabungsfragen und Begabtenförderung. Salzburg 13. Oktober 2000.

Ziegler, A. (2005). The actiotope model of giftedness. In R. J. Sternberg \& J. E. Davidson (Eds.), Conceptions of giftedness (pp. 411-434). New York: Cambridge University Press. 


\section{Biographical note}

Christian Fischer, PhD is full professor for Educational Sciences with a focus on School Research: Gifted Education and Individual Promotion at the University of Münster, Germany. He is academic director of the International Centre for the Study of Giftedness (ICBF) from the Universities of Münster, Osnabrück and Nijmegen (the Netherlands). He also is vice president of the European Council for High Ability (ECHA) and Program Director of the European Advanced Diploma in Educating the Gifted. He is member of the editorial board of the Austrian journal for gifted education and his publications focus on gifted education, individual promotion, learning difficulties and selfregulated learning.

KERSTIN MüLLER graduated from the University of Münster in summer 2013, where she earned a Master of Education in English and Religious Education. She also holds a Master of Arts in Teaching English to Speakers of Other Languages from Durham University, UK. In October 2013 she started her PhD on 'Religious Education in the US' at the University of Marburg. Since 2013 she has also been working for the International Centre for the Study of Giftedness in Münster. 